\title{
Integrating art and science to communicate the social and ecological complexities of wildfire and climate change in Arizona, USA
}

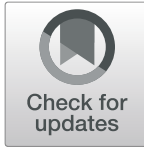

Melanie Colavito ${ }^{1}$, Barbara Satink Wolfson ${ }^{2^{*}}$ (D) Andrea E. Thode ${ }^{3}$, Collin Haffey ${ }^{4}$ and Carolyn Kimball ${ }^{5}$

\begin{abstract}
Background: This paper describes Fires of Change, a collaborative art exhibit designed to communicate about the shifting fire regimes of the United States Southwest through the lens of multimedia art. The Southwest Fire Science Consortium and Landscape Conservation Initiative, both of which are boundary organizations that facilitate collaboration among managers and scientists to develop and apply actionable science, organized Fires of Change by convening scientists, managers, and artists in the co-production of science-based artwork. Surveys were conducted with Fires of Change exhibit visitors to assess the impacts of viewing the exhibit, as well as with exhibit creators to assess the effects of participating in the project.

Results: The visitor survey results demonstrate that Fires of Change exhibits increased visitors' understanding of the effect of climate change on fire regimes and increased visitors' support for management actions to address the effects of climate change on fire behavior. The exhibit creator survey results demonstrate that the development of Fires of Change created new relationships and networks among the participants and increased appreciation for collaborations among scientists, managers, and artists. Specifically, science-management relationships, networks, and boundary organizations may have facilitated the project.
\end{abstract}

Conclusions: Fires of Change demonstrates that art can be an effective mechanism for communicating about complex ecological issues and that, by collaborating in the development of artwork, scientists and managers can create new partnerships.

Keywords: art, climate change, fire science, science communication, US Southwest

\footnotetext{
* Correspondence: Barbara.wolfson@nau.edu

${ }^{2}$ Southwest Fire Science Consortium, Northern Arizona University, PO Box

15018, Flagstaff, Arizona 86011, USA

Full list of author information is available at the end of the article
}

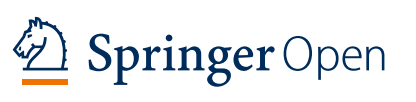

(c) The Author(s). 2020 Open Access This article is licensed under a Creative Commons Attribution 4.0 International License, which permits use, sharing, adaptation, distribution and reproduction in any medium or format, as long as you give appropriate credit to the original author(s) and the source, provide a link to the Creative Commons licence, and indicate if changes were made. The images or other third party material in this article are included in the article's Creative Commons licence, unless indicated otherwise in a credit line to the material. If material is not included in the article's Creative Commons licence and your intended use is not permitted by statutory regulation or exceeds the permitted use, you will need to obtain permission directly from the copyright holder. To view a copy of this licence, visit http://creativecommons.org/licenses/by/4.0/. 


\section{Resumen}

Antecedentes: Este trabajo describe Fuegos de Cambio, una exhibición de arte colaborativo diseñado para comunicar sobre los cambios en el régimen de fuegos en el Sudoeste de los EEUU a través de la visión del arte multimedia. El Consorcio de la Ciencia del Fuego del Sudoeste y la Iniciativa de Conservación del Paisaje, ambas organizaciones de ayuda que facilitan la colaboración entre gestores y científicos para desarrollar y aplicar ciencia práctica, organizaron Fuegos de Cambio convocando a científicos, gestores y artistas, en la coproducción de obras de arte basadas en la ciencia. Se realizaron encuestas a los visitantes de Fuegos de Cambio para valorar los impactos al observar la exhibición, como también a los creadores para evaluar los efectos de participar en el proyecto.

Resultados: Los resultados de la encuesta a los visitantes demostraron que Fuegos de Cambio experimentan un aumento de la comprensión del efecto del cambio climático en los regímenes de fuego, y un incremento del apoyo de los visitantes a las acciones de manejo para abordar los efectos del cambio climático en el comportamiento del fuego. El resultado de la encuesta a los creadores de la exhibición demostró que el desarrollo de Fuegos de Cambio creó nuevas relaciones y redes entre los participantes e incrementó la apreciación de las colaboraciones entre científicos, gestores y artistas. Específicamente, las relaciones entre la ciencia y el manejo, las redes y las organizaciones colaborativas pueden haber facilitado el proyecto.

Conclusiones: Fuegos de Cambio demuestra que el arte puede ser un mecanismo efectivo para comunicar cuestiones ecológicas complejas y que, colaborando en el desarrollo del trabajo artístico, científicos y gestores pueden crear nuevas alianzas.

\section{Introduction}

Over the last century, the dry forests of the United States Southwest, defined here as Arizona and New Mexico, have seen a shift from frequent, low-severity fire regimes to more infrequent, higher-severity fire regimes (Swetnam et al. 1999; Allen 2007). As a result, dry forests are burning outside their historic fire regimes with increased size, severity, and frequency (Wasserman 2020). Over the last two decades, the area burned and percent area burned at high severity has increased across forests and woodlands in the Southwest (Singleton et al. 2019). The increased severity and fire behavior are due to changes in fuel structure (Covington and Moore 1994), and more recently have been linked to climate warming (Littell et al. 2009; Abatzoglou and Williams 2016; Gonzalez et al. 2018; Mueller et al. 2020).

These ongoing changes to fire regimes in the Southwest affect fire managers, ${ }^{1}$ who must engage with diverse audiences that include scientists, policymakers, other land managers, and the general public about the complexities of fire ecology and associated management decisions. It can be challenging to communicate fire management decisions to the public, and local knowledge and education levels can affect community perceptions (Diaz et al. 2016). Proactive fire management that reduces fire risk can also be hampered by managers' perceptions of community pressure and expectations and by internal pressures within agencies (Steelman and McCaffrey 2011). Managers are required to use the best available science, but what that constitutes can be

\footnotetext{
${ }^{1}$ Fire managers are individuals who make decisions about the preparation for, suppression and implementation of, and recovery from fires.
}

unclear (Esch et al. 2018). Numerous individual characteristics, such as manager beliefs about research, willingness to experiment, and relationships with scientists, can affect how managers use science in decision making (Wright 2010). Science is mostly used by managers during the planning process and to inform treatment prescriptions (Hunter 2016).

To create a more robust understanding of and support for science-driven management, boundary organizations have emerged to bridge management, science, ${ }^{2}$ policy, and public spheres (Kocher et al. 2012). Boundary organizations are entities that develop and deliver actionable scientific information and facilitate ongoing dialogue among different knowledge spheres (Guston 2001; Cash et al. 2003). They facilitate science communication and the co-production of knowledge through collaborative processes with scientists and stakeholders focused on developing actionable scientific information (Meadow et al. 2015; Bremer and Meisch 2017). Knowledge coproduction has been demonstrated to facilitate the application of science in decision-making (Dilling and Lemos 2011; McNie 2013; Wall et al. 2017).

The Joint Fire Science Program (JFSP) Fire Science Exchange Network (FSEN) is an example of a boundary organization that works in fire and forest management. The FSEN consists of regional boundary organizations called Fire Science Exchanges (FSE) designed to facilitate science-to-action and knowledge exchange about wildland fire among scientists, managers, policymakers, and other stakeholders. Boundary organizations such as the

\footnotetext{
${ }^{2}$ Science is defined as the rigorous, systematic process of gathering, analyzing, and interpreting data about natural and social systems. Scientific information is the output of the scientific process.
} 
FSEs are beneficial for organizing information about fire science and strengthening relationships among fire scientists and managers (Kocher et al. 2012). The FSEs have consistently used multiple outreach methods and materials (e.g., conferences, workshops, webinars, field trips, and numerous virtual and written outputs) to interact with their audiences and have incorporated selfevaluation and learning methods into their outreach approaches to inform their strategic direction using audience feedback (Maletsky et al. 2018; Colavito et al. 2019).

Using audience and partner feedback and evaluations, FSEs have expanded the ways in which they facilitate collaboration and communicate to broader audiences. One example of this is combining management, science, and art. There is increasing attention on the intersection of science and art to communicate scientific concepts to broader audiences and garner support for management actions that embrace complexity and uncertainty (Swanson et al. 2008; Halpern 2012; Swanson 2015; Rathwell and Armitage 2016). Pairing scientific knowledge with other knowledge can draw attention to issues, facilitate communication, and reframe discussions (Miles 2010; Curtis et al. 2012; St. George et al. 2017). Collaborations between scientists and artists generate diversity of thought that allows for novel questions and unconventional application of science, which can encourage new science-management solutions (Scheffer et al. 2015; Thomsen 2015; Connelly et al. 2016). The arts engage different audiences and can create new lines of communication that enhance understanding of technical messages (Heras et al. 2016; Johansson and Isgren 2017).

Although there is significant potential for management, science, and art collaborations to garner understanding and support for science and management, understanding of how to effectively integrate science, management, and art is limited. Examples of projects that attempt this are needed. This paper highlights one such example from the Southwest, which took a new approach to communicating the impacts of climate change on forest and fire management through the lens of art. Fires of Change was a collaborative project that used art as a method to bridge multi-faceted ideas about fire science and management in a changing climate. The project was led by two boundary organizations: Southwest Fire Science Consortium (SWFSC, a JFSP FSE), and Landscape Conservation Initiative (LCI). ${ }^{3}$ Fires of Change sought to engage the public on the predicted changes to fire in a warming climate, promote understanding of science and management, and make

\footnotetext{
${ }^{3} \mathrm{LCI}$ is a research center at Northern Arizona University in Flagstaff, Arizona, that serves as a boundary organization by providing scientific research and community engagement for addressing conservation and environmental challenges in the Grand Canyon region and across the western US.
}

scientific information accessible to a wider audience. This paper provides information about the development of Fires of Change, surveys to assess its impacts, and a discussion of how science-management relationships, networks, and boundary organizations may have helped facilitate the project.

\section{Fires of Change Background}

In 2013, SWFSC, LCI, and Flagstaff Arts Council (FAC; Flagstaff, Arizona) partnered to develop the Fires of Change art exhibit to communicate about the shifting fire regimes of the Southwest through the lens of multimedia art. By creating an art exhibit about the modern alterations of the natural fire regime due to management practices and climate change, Fires of Change sought to reach broader audiences than those typically involved in land management conversations. The goal was to challenge these audiences to think differently-or for the first time-about what is being done to adapt wildland fire management to a warming climate and growing communities, and what steps could be taken to help ensure a sustainable future for communities and forests. This work was inspired by In a Time of Change: The Art of Fire, a project led by the Alaska Fire Science Consortium from 2012 to 2013 (Trainor et al. 2013) and Burnished Landscapes (2013), an art-science project coled by LCI and Flagstaff-based artist, Kate Aitchison. The Fires of Change partners covered a broad suite of fire ecology and management topics during educational field trips for artists. The depth of science translation was carried through to the exhibit and was adapted for attendees.

In the fall of 2013, FAC solicited applications from artists, locally and nationally. They selected 11 artists who work in a range of media, such as quilting, filmmaking, ceramics, poetry, drawing, and mixed-media installations. SWFSC and LCI drew upon their networks of fire professionals and scientists and experience with field education programs to design a four-day fire-science and management field trip or "bootcamp" in September of 2014 on the North Rim of the Grand Canyon, on lands managed by the US National Park Service and USDA Forest Service, and other fire-affected areas in northern Arizona. The 11 artists, 14 project staff and fire science professionals, and three media and art organization staff spent four days immersed in the ecological, historical, and spatial landscapes of fire in the Southwest. During the bootcamp, the artists were tasked with learning scientific information about the complexity of fire issues, including those that climate change and human intervention have modified, in dry conifer forests in the Southwest (Fig. 1). The bootcamp offered a relationship-building experience in which researchers, managers, and artists mingled. The artists relied on these 


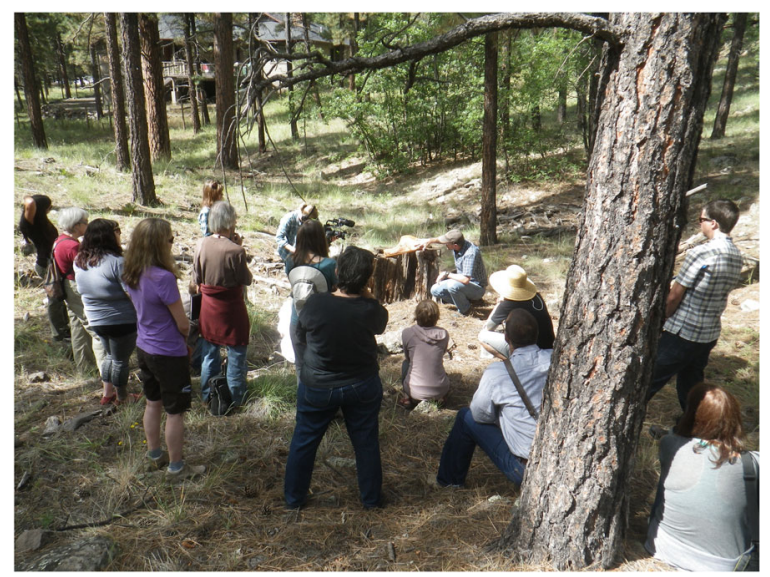

Fig. 1 Managers, scientists, and artists listen to a presentation during the bootcamp portion of the Fires of Change project in Flagstaff, Arizona, USA, in the fall of 2014. Photo by Collin Haffey

relationships during their creative processes, which further incorporated science into their final artwork (Figs. 2 and 3). For example, one artist kept in touch with agency representatives to ensure accurate depiction of fire relationships in fabric artwork (Figs. 4 and 5).

The Fires of Change exhibit was designed to look at fire management and climate change in a unique, multifaceted approach. In addition to the exhibit, the project organizers arranged seven science lectures, most paired with artist presenters, to draw more community members into the conversation about fire and climate in the Southwest. This allowed for science interpretation by scientists and explanations of how artists integrated science into their art. Organizers also facilitated production of three videos: two that provided a description of the project process (Fires of

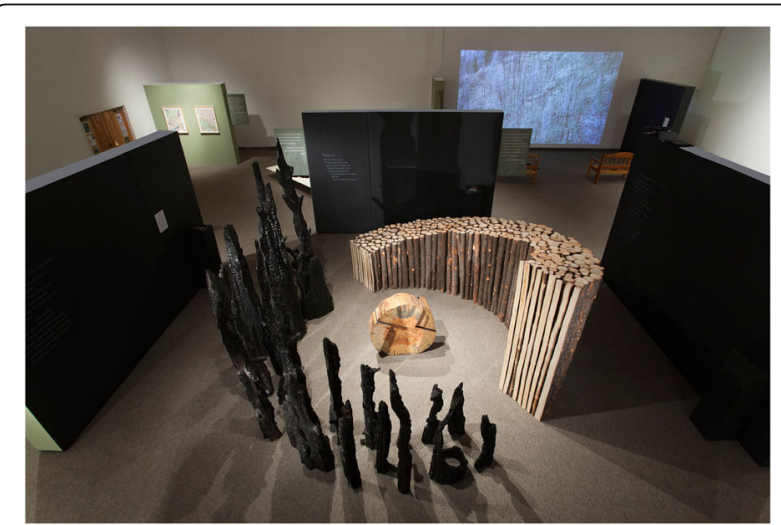

Fig. 2 Fires of Change exhibit in Flagstaff, Arizona, USA, in the fall of 2015, depicting Bryan David Griffith's piece entitled "Broken

Equilibrium." Relevant science and management quotes can be seen on the green poster-sized boards in the background. This photo is an example of what the exhibit looked like to attendees and survey respondents in Flagstaff, Arizona. Photo by Tom Alexander

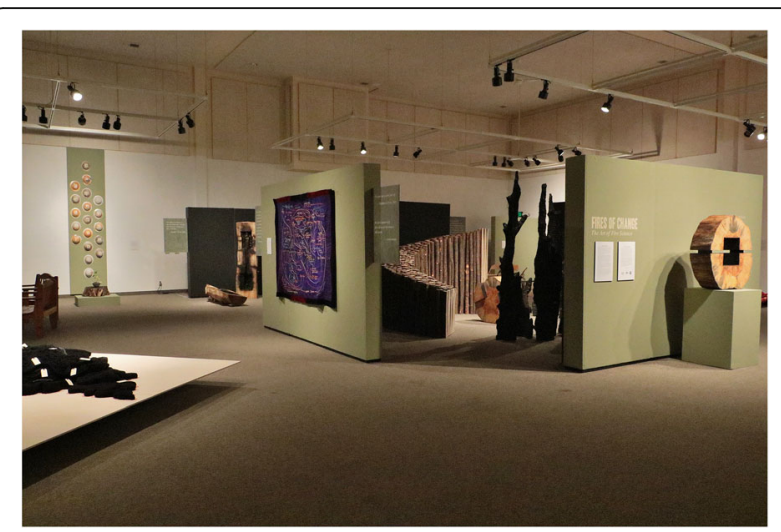

Fig. 3 Overview of the Fires of Change exhibit in Flagstaff, Arizona, USA, in the fall of 2015. This photo is another example of what the exhibit looked like to attendees and survey respondents in Flagstaff, Arizona. Photo by Shawn Skabelund

Change - Part 1, Fires of Change - Part 2) and one that discussed the basic science on which the art was based (Fires of Change - Science Video). The basic science video played on a loop throughout the 2015 exhibit in Flagstaff and all were available on exhibit websites. Lastly, there were several poster-sized signs at the exhibit with historically influential quotes from scientific journal articles, policy documents, and books on fire history and management dating from 1943 to 2014 (Figs. 6 and 7). The exhibit website (https://www.swfireconsortium.org/fires-of-change/) and exhibit catalog provide additional details about the artwork (Flagstaff Arts Council 2016).

The Fires of Change exhibit was shown at three locations: Flagstaff, Arizona, from September to October 2015; Tucson, Arizona, from November 2015 to April 2016; and

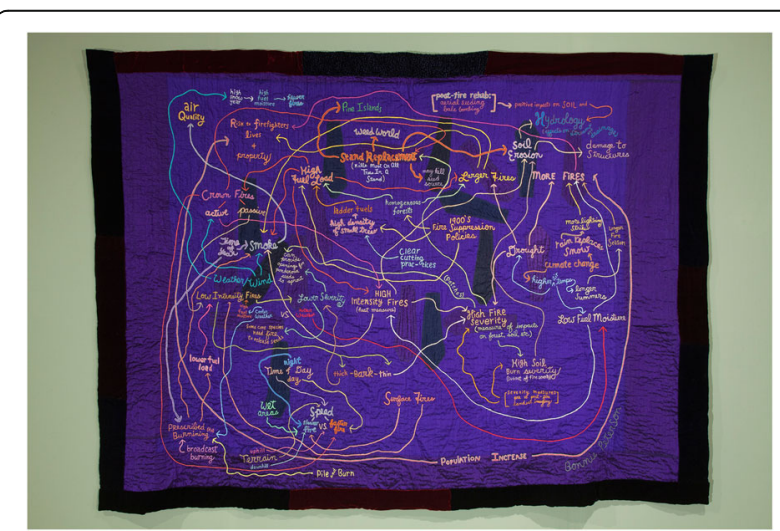

Fig. 4 Fires of Change exhibit in Flagstaff, Arizona, USA, in the fall of 2015, depicting Bonnie Peterson's fabric art entitled, "On the Nature of Fire." This photo provides an example of how one artist interpreted scientific information into her artwork. In the artist's statement, Bonnie Peterson notes, "This work explores the language of wildfires and their environmental connections" (Flagstaff Arts Council 2016). Photo by Tom Alexander 


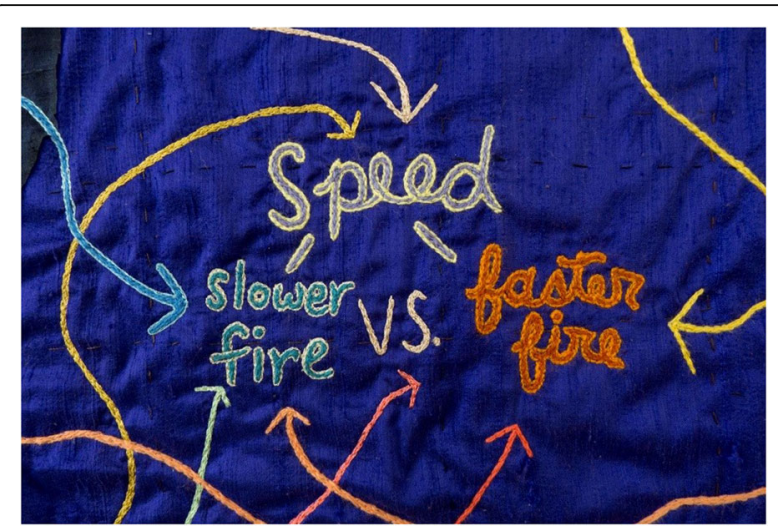

Fig. 5 Fires of Change exhibit in Flagstaff, Arizona, USA, in the fall of 2015, showing a detail from Bonnie Peterson's fabric art entitled, "On the Nature of Fire" (see Fig. 4). Photo by Tom Alexander

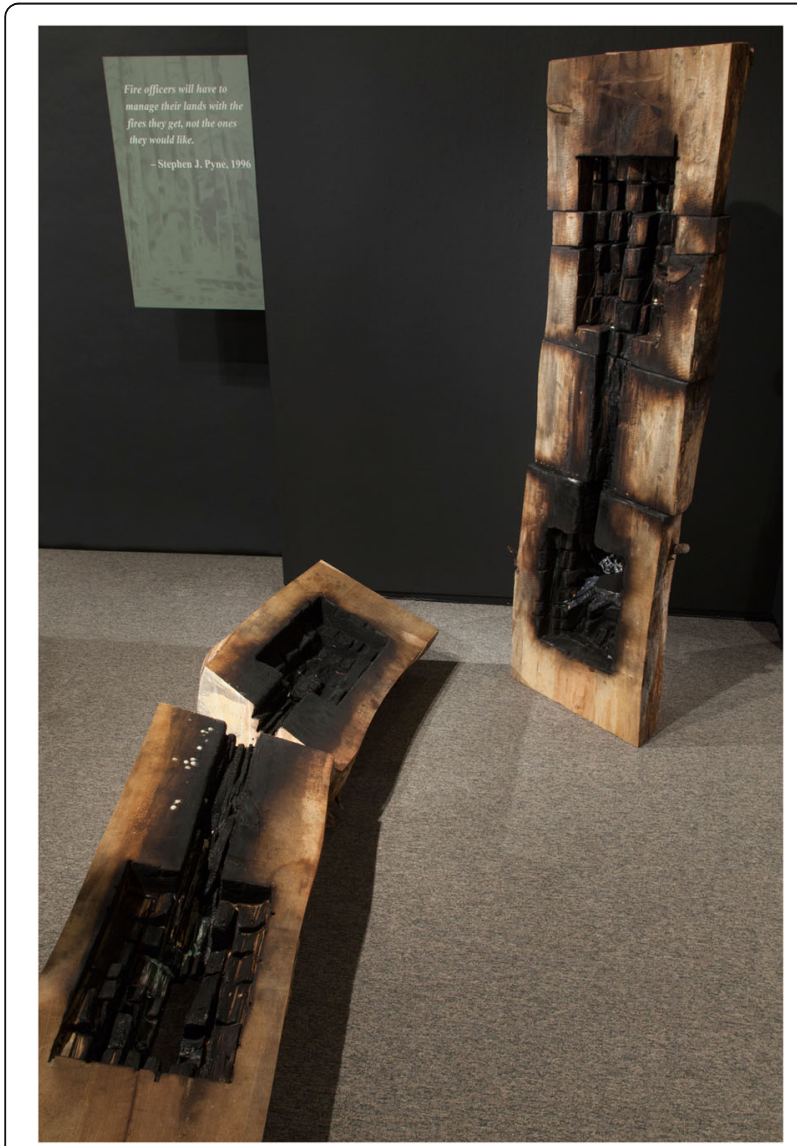

Fig. 6 Fires of Change exhibit in Flagstaff, Arizona, USA, in the fall of 2015, depicting Craig Goodworth's art entitled, "Fire Renderings," with a quote by Stephen J. Pyne, "Fire officers will have to manage their lands with the fires they get, not the ones they would like," in the background. This photo provides an example of how relevant scientific quotations were paired with artwork at the exhibit in order to enhance the public education portion of the project. Photo by Tom Alexander
Albuquerque, New Mexico, from May to July 2018. The Flagstaff exhibit included the art, paired artist-scientist presentations, videos, and quotation posters. The Tucson exhibit included the art, paired artist-scientist presentations, and quotation posters. The third exhibit in Albuquerque included paired artist-scientist presentations and a family day with presentations oriented toward children. To increase visitation, partnering organizations advertised the exhibit to their email and membership lists and on social media. Organizers shared information with agency public affairs staff, and the USDA Forest Service Southwestern Region scheduled a group visit that included the Regional Forester to the Albuquerque exhibit. In Flagstaff, public radio ads and listings within the Flagstaff Festival of Science program were used to advertise the exhibit. Reaching out to multiple audiences-supporters of both the arts and sciences-generated positive results. Across the three venues, nearly 12000 people viewed the exhibit.

\section{Fires of Change surveys}

Exhibit visitor surveys were conducted to collect information about the exhibit's impact on the general public's understanding and perceptions of fire science and management in Flagstaff and Tucson. No surveys were conducted in Albuquerque. The exhibit visitor surveys were the same in Flagstaff and Tucson except for a question about exhibit advertisement (Additional file 1). Respondents self-selected to complete a paper survey after viewing the exhibit. In Flagstaff, volunteers solicited respondents during exhibit events, and paper surveys were left at the exhibit exit during regular hours. In Tucson, surveys were only available at the exhibit exit during regular hours. There were 115 total respondents: 69 in Flagstaff and 46 in Tucson.

Exhibit creator surveys were also conducted for the SWFSC Executive Board, artists, and scientists and managers involved in the exhibit development to gather information about their experiences participating in Fires of Change (Additional file 2). The surveys were administered online using Survey Monkey and distributed by email by the SWFSC. There were 24 exhibit creator respondents, including 11 SWFSC Executive Board members, nine artists, and four scientists or managers. The board members did not participate in the project development and dissemination, but their perspectives were included, as they help to set SWFSC's goals and direction.

Both the exhibit visitor and creator surveys were designed to be short evaluations to provide the SWFSC with basic insight about the outcomes of Fires of Change. Due to the use of convenience sampling and small sample sizes, only descriptive statistics are provided and no statistical conclusions are drawn. Open-ended survey 


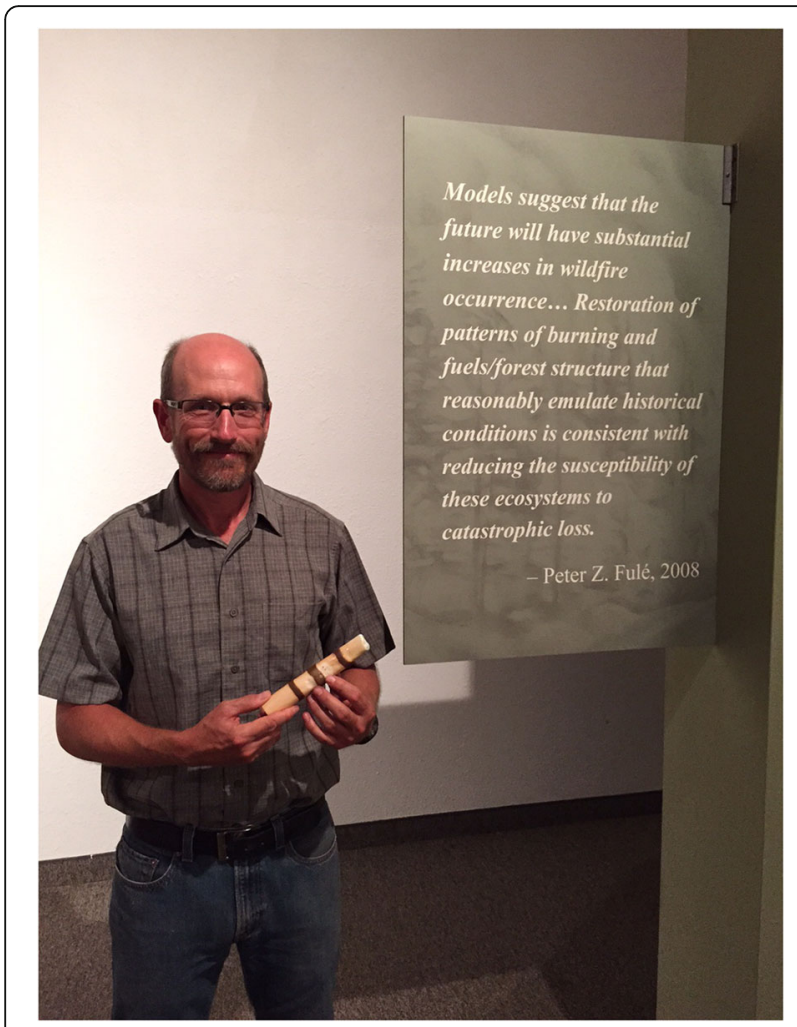

Fig. 7 Fires of Change exhibit in Flagstaff, Arizona, USA, in the fall of 2015, depicting Peter Z. Fulé, an ecologist and professor at Northern Arizona University, with a scientific quote from his research. This photo provides an example of how scientific information was integrated into the exhibit along with the artwork. Photo by Andi Thode

questions were organized according to general themes, but no formal qualitative analysis was done.

\section{Results}

\section{Fires of Change visitor survey}

Visitor survey respondents were asked to rate their level of understanding of how climate change is affecting fire regimes in the Southwest before and after attending Fires of Change. Results were reported with Flagstaff and Tucson respondents combined. Only $20.87 \%$ of respondents self-reported an advanced level of understanding before attending the exhibit, but after attending the exhibit, $34.78 \%$ of respondents reported advanced understanding (Fig. 8). The majority of respondents had at least a moderate $(38.26 \%)$ or basic $(33.04 \%)$ understanding of how climate change is affecting fire regimes in the Southwest prior to attending the exhibit. After attending the exhibit, $57.39 \%$ of respondents expressed a moderate understanding (Fig. 8).

Respondents were also asked to report the degree to which they were more or less likely to accept local management actions designed to address the effects of climate change on fire behavior after viewing the exhibit.
The majority of respondents were more likely (75.65\%) to support local management actions, while $21.74 \%$ of respondents expressed no change in opinion. One respondent $(0.87 \%)$ was less likely to support management action.

Comments in the surveys provided additional insight into the impact of combining artistic and scientific perspectives. For example, one respondent stated, "The artist and scientist talks were extremely informative and provided important context for understanding the works of art." Another respondent noted, "The blending of art and science is such an important way to bridge understanding." Respondents commented on the emotional impact of the exhibit. One stated, "The art not only increases our intellectual understanding of the impact of climate change, but more importantly the emotional level. It is there where change takes place." On the other hand, one respondent noted, "Barely any of the art actually touches [on] regeneration and restoration. The artists mostly tell a story of destruction and mismanagement, not of complexity and scientific uncertainty."

\section{Fires of Change exhibit creator survey}

Exhibit creators were asked to indicate their level of agreement with the statement, "Art can be an effective mechanism for building public awareness and understanding about important issues such as fire and climate science" (Additional file 2). Seventy-nine percent of respondents strongly agreed, and $21 \%$ agreed with the statement. The artist group $(n=9)$ strongly agreed (89\%) or agreed $(11 \%)$ that their involvement in Fires of Change had inspired them to discuss fire and climate science with others. Sixty-seven percent of the artist participants indicated that they had shared their knowledge of fire and climate science with more than 21 people. The artists spoke positively about the field trips and inperson interactions while creating the exhibit. One respondent noted,

The tours to the forests, the fire station, and especially the more interactive and hands-on experiences (fire-truck tools and equipment tour, getting tree-core samples) were my favorite. Also, the opportunity to exchange ideas with the artists and scientists more casually was great.

Artists also noted positive outcomes to their careers due to participation in the project. For example, one artist stated,

It was a challenge that I liked to take on. It forced me to speak, think, and feel about a topic that I normally would not consider in my work. It gave me the opportunity to make art with a community of 
"PRIOR (light gray) to and AFTER (dark gray) attending the

Fires of Change Exhibit, how would you rate your level of understanding about how climate change is currently affecting fire regimes in the Southwest?"

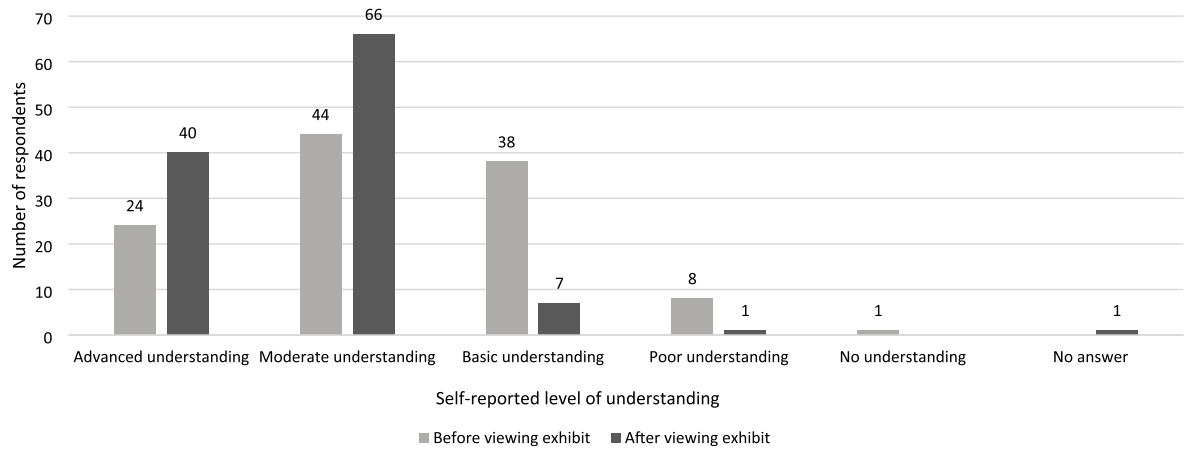

Fig. 8 Responses to two survey questions that asked exhibit attendees to self-report their level of understanding about how climate change is currently affecting fire regimes in the Southwest before (light gray) and after (dark gray) attending the Fires of Change exhibit. Surveys were conducted in Flagstaff, Arizona, in fall 2015, and Tucson, Arizona, in spring 2016. Results from both locations are combined. Surveys were designed to collect information about the general public's level of understanding of fire science and management

artists for the public with a specific goal and outcome.

The scientist and manager group $(n=4)$ agreed $(75 \%)$ or strongly agreed (25\%) that the exhibit accurately reflected the scientific message that they hoped to convey. This group also strongly agreed (50\%) or agreed (25\%) that their involvement had inspired them to discuss fire and climate with a non-scientific audience. Furthermore, $50 \%$ indicated that they had shared their experience with 11 to 20 colleagues, and $25 \%$ had shared with more than 21 colleagues. This group also appreciated the field trips. One respondent noted, "The most effective elements were the unstructured conversations... These allowed two-way conversation and mutual understanding of the topics." This group also expressed positive outcomes from their participation. One manager stated, "It was a great experience to see different perspectives (from the artists) on the work I do every day." And one scientist noted, "This project changed the way I see using art to share science and I am a true believer now."

The Executive Board $(n=11)$ strongly agreed $(55 \%)$ or agreed (36\%) that they would support a similar project in the future. Only four board respondents attended the exhibit due to geographic limitations, but those attendees all agreed that it was an effective mechanism for building public awareness and understanding about fire and climate science. For example, one stated,

Public awareness and outreach are challenging. The Fires of Change project represents an innovative and creative way to bring awareness to the public without the typical negative overtones of using fire to manage the landscape. These types of projects should be continued/funded once every two years.

Another noted, "Fires of Change was a fantastic project that opened my eyes to how powerful a science-art collaboration can be!"

\section{Discussion}

This example of a science-based art exhibit adds to the ever-strengthening hypothesis that joining scientific information and artistic impression can shift the public conversation about ecological issues (Scheffer et al. 2015; Jacobson et al. 2016; Rathwell and Armitage 2016). Although the qualitative nature of the surveys and small sample do not allow for robust scientific conclusions, a number of possible explanations may have facilitated the outcomes of Fires of Change.

\section{Fires of Change outcomes}

The visitor survey results indicate that, for those surveyed, Fires of Change increased reported understanding about fire and climate change. Respondents were also more likely to support active fire management (e.g., mechanical fuels reduction and prescribed burns) to address climate change. Flagstaff residents possess relatively high levels of formal educational attainment (e.g., $45.1 \%$ of persons 25 years or older has a bachelor's degree or higher, US Census Bureau 2019) and are relatively savvy and supportive of management action to address fire behavior and effects (Diaz et al. 2016). That an art exhibit could enhance public engagement in management in a place where people are already somewhat attuned to these issues points to the promise of this method. 
Exhibit creators reported that their experience participating in Fires of Change had a positive impact. For example, the project inspired the majority of artists, scientists, and managers to speak with a broader audience about fire and climate change. One of the strengths of bringing artists, scientists, and managers together for this project was the opportunity to weave social and knowledge networks together to communicate about complex scientific and management concepts (Feldman and Ingram 2009; Owen et al. 2012). The artists who participated in the project can also act as ambassadors or conduits of ecological knowledge to their communities (Heras et al. 2016; Johansson and Isgren 2017). An artist may be a more compelling communicator to different subsets of the community than a scientist or manager.

The benefits derived from Fires of Change are not, of course, without costs. All of the partnering organizations devoted staff time to orchestrate the project. The bootcamp required funding for travel costs, meals, and stipends for artists and presenters. Additional resources paid for materials to create the art, build the exhibit, and advertise the exhibit and associated events. While these were significant investments, the project delivered a high return on investment through the engagement with novel audiences and increased public understanding of fire ecology and management. It is worthy of replication in other geographies and disciplines.

While the survey results are encouraging, they only represent a self-selected, and therefore biased, sample of survey respondents who: (1) came to an art exhibit about fire and climate, and (2) were willing to complete a survey. Similarly, the artists, scientists, and managers who participated in the project opted in to the experience because they liked the idea of combining science and art. Nonetheless, the results provide insights for designing future research to understand the impact of interdisciplinary collaborations to communicate science. Future research should explore the effect of art on larger populations and identify the outcomes and impacts of collaborative efforts among scientists, artists, and managers.

\section{Relationship and network building}

The process of developing Fires of Change generated new relationships, trust, and knowledge networks among exhibit creators. For example, the bootcamp process facilitated the development of new relationships among artists, managers, and scientists, and created credibility and trust that allowed for more knowledge sharing (Peters et al. 1997). The bootcamp agenda was designed to allow participants to process information together, learn about each other, and build trust. Throughout the process, developing relationships and increasing trust led to more open dialogue, greater comfort in asking questions, and sustained interactions following the bootcamp. The relationships built in this process likely strengthened the artwork and understanding between art and science (Swanson 2015).

One potential shortcoming of the process was that the interactions among the exhibit creators were left to informally continue as needed following the bootcamp, rather than being actively facilitated. Because of the short duration of the bootcamp, artists may have felt overwhelmed with such a large amount of information in a short period of time. Changes in the structure of this process could help spread the flow of information across a longer period.

\section{Importance of boundary organizations}

Fires of Change represented a new approach by two boundary organizations-SWFSC and LCI-to expand their outreach methods and materials and incorporate new artistic perspectives into the conversation about fire science and management. The SWFSC and LCI used their convening, translating, and collaborating functions (Buizer et al. 2016) to coordinate the bootcamp and formed a new partnership with FAC for the subsequent development of science-based artwork. Fires of Change was also an opportunity for SWFSC and LCI to engage with and learn from artists who work to communicate and create change in realms beyond fire and climate science and management (e.g., Swanson et al. 2008). The Fires of Change process required ongoing, sustained interaction among the project participants. Thus, it represented a form of knowledge coproduction (Bremer and Meisch 2017), specifically, science-based art designed to reach a broader audience and produce actionable outcomes in the form of increased understanding of and support for fire management.

The facilitation provided by SWFSC and LCI may have resulted in numerous benefits to participants. For example, novel partnerships among scientists, managers, and artists emerged, which helped catalyze new ideas and energize participants (Jacobson et al. 2016). Scientist participants felt that they were able to effectively communicate science to both artists and exhibit attendees, and managers may see greater support from within the community for their management actions based on the survey results. If gaining the support of local communities is necessary to implement land management projects (Diaz et al. 2016), engaging boundary organizations may bridge gaps and enable projects to move forward.

\section{Conclusion}

Fires of Change, a collaborative art exhibit designed to communicate about the shifting fire regimes of the 
Southwest through the lens of multimedia art, served as proof of concept that art can be an effective mechanism for (1) increasing understanding of fire and climate change; (2) building public support for management actions; and (3) developing partnerships among diverse science, management, and artistic audiences. The Fires of Change example highlights the role that boundary organizations can play in facilitating collaboration among science and management spheres, creating new spaces for innovation and adaptation, and enhancing communication of technical and scientific messages to the general public. Relationships built during the Fires of Change process appear to have strengthened understanding across science, management, and artist participants. Future research is needed to validate these preliminary conclusions and explore future collaborations that merge arts, science, and management with more robust survey methodology and sample sizes. Nonetheless, future art, science, and management collaborations like Fires of Change should be replicated to encourage complex, interdisciplinary conversations and relationships among artists, scientists, and managers to find innovative solutions to the challenges presented by climate change and fire.

\section{Supplementary information}

Supplementary information accompanies this paper at https://doi.org/10. 1186/s42408-020-00078-W.

Additional file 1. Fires of Change exhibit attendee surveys conducted during the fall of 2015 in Flagstaff, Arizona, and the spring of 2016 in Tucson, Arizona, USA.

Additional file 2. Fires of Change creator survey for artists, scientists and managers, and Southwest Fire Science Consortium Executive Board members who participated in the development of the exhibit development. The surveys were conducted online with Survey Monkey during the summer 2016

\section{Acknowledgements}

We would like to acknowledge the important contributions of several groups of people, without whom this project could not have succeeded: the 11 artists in the exhibit; the managers and scientists who developed and participated in the field trip and workshop; our visionary curator S. Skabelund; and the tireless J. Tannous, formerly of the Flagstaff Arts Council. Funding was provided by the Joint Fire Science Program and the National Endowment for the Arts.

\section{Authors' contributions}

$M C$ developed the visitor survey instruments and analyzed the data, as well as led the writing of the manuscript. BSW organized and led the field trip and exhibit development, developed the exhibit creator surveys, and participated in writing the manuscript. AT organized and led the field trip and exhibit development and participated in writing the manuscript. $\mathrm{CH}$ organized and led the field trip and exhibit development, and participated in writing the manuscript. CK organized and led the field trip and exhibit development and participated in writing the manuscript. All authors read and approved the final manuscript.

\section{Funding}

Funding was provided by the Joint Fire Science Program, the National Endowment for the Arts, and the Olajos-Goslow Endowment. The funding bodies did not have a role in the study or manuscript.

\section{Availability of data and materials}

Datasets used and analyzed during the current study are available from the corresponding author on reasonable request.

\section{Ethics approval and consent to participate}

The surveys for this project were reviewed and approved by the Northern Arizona University Institutional Review Board. Consent to participate in a survey was obtained from each subject.

\section{Consent for publication}

Consent to publish the photographs of artwork was obtained from the photographer and artists.

\section{Competing interests}

The authors declare that they have no competing interests.

\section{Author details}

${ }^{1}$ Ecological Restoration Institute, Northern Arizona University, PO Box 15017, Flagstaff, Arizona 86011, USA. ${ }^{2}$ Southwest Fire Science Consortium, Northern Arizona University, PO Box 15018, Flagstaff, Arizona 86011, USA. ${ }^{3}$ School of Forestry, Southwest Fire Science Consortium, Northern Arizona University, PO Box 15018, Flagstaff, Arizona 86011, USA. ${ }^{4}$ The Nature Conservancy, Landscape Conservation Initiative, 1613 Paseo de Peralta, Santa Fe, New Mexico 87501, USA. ${ }^{5}$ Montana Environmental Information Center, Landscape Conservation Initiative, PO Box 1184, Helena, Montana 59624, USA.

Received: 10 February 2020 Accepted: 8 July 2020

Published online: 02 September 2020

\section{References}

Abatzoglou, J.T., and A.P. Williams. 2016. Impact of anthropogenic climate change on wildfire across western US forests. Proceedings of the National Academy of Sciences 113: 11770-11775. https://doi.org/10.1073/pnas. 1607171113

Allen, C.D. 2007. Interactions across spatial scales among forest dieback, fire, and erosion in Northern New Mexico landscapes. Ecosystems 10 (5): 797-808. https://doi.org/10.1007/s10021-007-9057-4.

Bremer, S., and S. Meisch. 2017. Co-production in climate change research: Reviewing different perspectives. WIREs Climate Change 8 (6): e482. https:// doi.org/10.1002/wcc.482.

Buizer, J., K. Jacobs, and D. Cash. 2016. Making short-term climate forecasts useful: Linking science and action. Proceedings of the National Academy of Sciences 113 (17): 4597-4602. https://doi.org/10.1073/pnas.0900518107.

Cash, D.W., W.C. Clark, F. Alcock, N.M. Dickson, N. Eckley, D.H. Guston, J. Jager, and R.B. Mitchell. 2003. Knowledge systems for sustainable development. Proceedings of the National Academy of Sciences 100 (14): 8086-8091. https:// doi.org/10.1073/pnas.1231332100

Colavito, M.M., S. Trainor, N. Kettle, and A. York. 2019. Making the transition from science delivery to knowledge co-production in boundary spanning: A case study of the Alaska Fire Science Consortium. Weather, Climate, and Society 11 (4): 917-934. https://doi.org/10.1175/WCAS-D-19-0009.1.

Connelly, A., S. Guy, E. Wainwright, W. Weileder, and M. Wilde. 2016. Catalyst: Reimagining sustainability with and through fine art. Ecology and Society 21 (4). https://doi.org/10.5751/ES-08717-210421.

Covington, W.W., and M.M. Moore. 1994. Southwestern ponderosa forest structure: Changes since Euro-American settlement. Journal of Forestry 92 (1): $39-47$

Curtis, D., N. Reid, and G. Ballard. 2012. Communicating ecology through art: What scientists think. Ecology and Society 17 (2). https://doi.org/10.5751/ES04670-170203.

Diaz, J.M., T. Steelman, and B. Nowell. 2016. Local ecological knowledge and fire management: What does the public understand? Journal of Forestry 114 (1): 58-65. https://doi.org/10.5849/jof.14-026

Dilling, L., and M.C. Lemos. 2011. Creating usable science: Opportunities and constraints for climate knowledge use and their implications for science 
policy. Global Environmental Change 21 (2): 680-689. https://doi.org/10.1016/j. gloenvcha.2010.11.006.

Esch, B.E., A.E.M. Waltz, T.N. Wasserman, and E.L. Kalies. 2018. Using best available science information: Determining best and available. Journal of Forestry 116 (5): 473-480. https://doi.org/10.1093/jofore/fvy037.

Feldman, D.L., and H.M. Ingram. 2009. Making science useful to decision makers: Climate forecasts, water management, and knowledge networks. Weather, Climate, and Society 1: 9-21. https://doi.org/10.1175/2009WCAS1007.1.

Flagstaff Arts Council. 2016. In Fires of Change Catalog, ed. J. Tannous Available online: https://flagartscouncil.org/wp-content/uploads/2016/01/ FiresofChangeCatalog-Webmark-2.pdf. Accessed 20 May 2020.

Gonzalez, P., G.M. Garfin, D.D. Breshears, K.M. Brooks, H.E. Brown, E.H. Elias, A. Gunasekara, N. Huntly, J.K. Maldonado, N.J. Mantua, H.G. Margolis, S. McAfee, B.R. Middleton, and B.H. Udall. 2018. In Southwest. P. 1101-1184 in Impacts, Risks, and Adaptation in the United States: Fourth National Climate Assessment, ed. D.R. Reidmiller, C.W. Avery, D.R. Easterling, K.E. Kunkel, K.L.M. Lewis, T.K. Maycock, and B.C. Stewart, vol. II. Washington, DC: U.S. Global Change Research Program. https://doi.org/10.7930/NCA4.2018.CH25.

Guston, D.H. 2001. Boundary organizations in environmental policy and science: An introduction. Science, Technology, \& Human Values 26 (4): 399-408. https://doi.org/10.1177/016224390102600401.

Halpern, M.K. 2012. Across the great divide: Boundaries and boundary objects in art and science. Public Understanding of Science 21 (8): 922-937. https://doi org/10.1177/0963662510394040

Heras, M., J.D. Tabara, and A. Meza. 2016. Performing biospheric futures with younger generations: A case in the MAB Reserve of La Sepultura, Mexico. Ecology and Society 21 (2). https://doi.org/10.5751/ES-08317-210214.

Hunter, M.E. 2016. Outcomes of fire research: Is science used? International Journal of Wildland Fire 25 (5): 495-504. https://doi.org/10.1071/WF15202.

Jacobson, S., J. Seavey, and R. Mueller. 2016. Integrated science and art education for creative climate change communication. Ecology and Society 21 (3). https://doi.org/10.5751/ES-08626-210330.

Johansson, E., and E. Isgren. 2017. Local perceptions of land-use change: Using participatory art to reveal direct and indirect socioenvironmental effects of land acquisitions in Kilombero Valley, Tanzania. Ecology and Society 22 (1). https://doi.org/10.5751/ES-08986-220103.

Kocher, S.D., E. Toman, S.F. Trainor, V. Wright, J.S. Briggs, C.P. Goebel, E.M. MontBlanc, A. Oxarart, D.L. Pepin, TA. Steelman, A. Thode, and T.A. Waldrop. 2012. How can we span the boundaries between wildland fire science and management in the United States? Journal of Forestry 110 (8): 421-428. https://doi.org/10.5849/jof.11-085.

Littell, J.S., D. McKenzie, D.L. Peterson, and A.L. Westerling. 2009. Climate and wildfire area burned in western US ecoprovinces, 1916-2003. Ecological Applications 19 (4): 1003-1021. https://doi.org/10.1890/07-1183.1.

Maletsky, L.D., W.P. Evans, L. Singletary, and L.L. Sicafuse. 2018. Joint Fire Science Program (JFSP) Fire Science Exchange Network: A national evaluation of initiative impacts. Journal of Forestry 116 (4): 328-335. https://doi.org/10.1093/ jofore/fvy009.

McNie, E.C. 2013. Delivering climate services: Organizational strategies and approaches for producing useful climate-science information. Weather, Climate, and Society 5 (1): 14-26. https://doi.org/10.1175/WCAS-D-11-00034.1.

Meadow, A.M., D.B. Ferguson, Z. Guido, A. Horangic, G. Owen, and T. Wall. 2015. Moving toward the deliberate coproduction of climate science knowledge. Weather, Climate, and Society 7 (2): 179-191. https://doi.org/10.1175/WCAS-D14-00050.1.

Miles, M. 2010. Representing nature: Art and climate change. Cultural Geographies 17 (1): 19-35. https://doi.org/10.1177/1474474009349997.

Mueller, S.E., A.E. Thode, E.Q. Margolis, L.L. Yocom, J.D. Young, and J.M. Iniguez 2020. Climate relationships with increasing wildfire in the southwestern US from 1984 to 2015. Forest Ecology and Management 460: 117861. https://doi. org/10.1016/j.foreco.2019.117861.

Owen, G., J.D. McLeod, C.A. Kolden, D.B. Ferguson, and T.J. Brown. 2012. Wildfire management and forecasting fire potential: The roles of climate information and social networks in the Southwest United States. Weather, Climate, and Society 4 (2): 90-102. https://doi.org/10.1175/WCAS-D-11-00038.1.

Peters, R.G., V.T. Covello, and D.B. McCallum. 1997. The determinants of trust and credibility in environmental risk communication: An empirical study. Risk Analysis 17 (1): 43-54. https://doi.org/10.1111/j.1539-6924.1997.tb00842.x.

Rathwell, K., and D. Armitage. 2016. Art and artistic processes bridge knowledge systems about social-ecological change: An empirical examination with Inuit artists from Nunavut, Canada. Ecology and Society 21 (2). https://doi.org/10. 5751/ES-08369-210221.
Scheffer, M., J. Bascompte, T. Bjordam, S. Carpenter, L. Clarke, C. Folke, P. Marquet, N. Mazzeo, M. Meerhoff, O. Sala, and F. Westley. 2015. Dual thinking for scientists. Ecology and Society 20 (2). https://doi.org/10.5751/ES-07434-200203.

Singleton, M.P., A.E. Thode, A.J.S. Meador, and J.M. Iniguez. 2019. Increasing trends in high-severity fire in the southwestern USA from 1984 to 2015. Forest Ecology and Management 433: 709-719. https://doi.org/10.1016/j. foreco.2018.11.039.

St. George, S., D. Crawford, T. Reubold, and E. Giorgi. 2017. Making climate data sing: Using music-like sonifications to convey a key climate record. Bulletin of the American Meteorological Society 98 (1): 23-27. https://doi.org/10.1175/ BAMS-D-15-00223.1.

Steelman, T.A., and S.M. McCaffrey. 2011. What is limiting more flexible fire management-public or agency pressure? Journal of Forestry 109 (8): 454-461.

Swanson, F.J. 2015. Confluence of arts, humanities, and science at sites of longterm ecological inquiry. Ecosphere 6 (8): 1-23. https://doi.org/10.1890/ES1500139.1.

Swanson, F.J., C. Goodrich, and K.D. Moore. 2008. Bridging boundaries: Scientists, creative writers, and the long view of the forest. Frontiers in Ecology and the Environment 6 (9): 499-504. https://doi.org/10.1890/070076.

Swetnam, T.W., C.D. Allen, and J.L. Betancourt. 1999. Applied historical ecology: Using the past to manage for the future. Ecological Applications 9 (4): 1189 1206. https://doi.org/10.1890/1051-0761(1999)009[1189:AHEUTP]2.0.CO;2.

Thomsen, D. 2015. Seeing is questioning: Prompting sustainability discourses through an evocative visual agenda. Ecology and Society 20 (4). https://doi. org/10.5751/ES-07925-200409.

Trainor, S.F., M.B. Leigh, K. Franzen, and J.L. Hrobak. 2013. In a time of change: the art of fire - Final Report to the Joint Fire Science Program. JFSP Project No. 11-S2-2, 10. Fairbanks: University of Alaska.

United States Census Bureau. 2019. Flagstaff city, Arizona QuickFacts: https:// www.census.gov/quickfacts/fact/table/flagstaffcityarizona/EDU63521 7\#EDU635217. Accessed 17 July 2019.

Wall, T.U., E. McNie, and G.M. Garfin. 2017. Use-inspired science: Making science usable by and useful to decision makers. Frontiers in Ecology and the Environment 15 (10): 551-559. https://doi.org/10.1002/fee.1735.

Wasserman, T.N. 2020. Wildfire Trends Across the Western US: Forest Fires Have Increased in Size, Severity, and Frequency Across Western Forests, ERI White Paper - Issues in Forest Restoration, 10. Ecological Restoration Institute, Northern Arizona University. https://cdm17192.contentdm.oclc.org/digital/ collection/p17192coll1/id/1043/rec/10?utm_source=ERI+Combined+ Emails\&utm_campaign=d077ce5e29-Science_Flash_Spring_September_201 9_COPY_01\&utm_medium=email\&utm_term=0_aa3b336279-d077ce5e2 9-345748349.

Wright, V. 2010. Influences to the success of fire science delivery: Perspectives of potential fire / fuels science users. Final Report to the Joint Fire Science Program, JFSP Project \#04-4-2-01.

\section{Publisher's Note}

Springer Nature remains neutral with regard to jurisdictional claims in published maps and institutional affiliations.

\section{Submit your manuscript to a SpringerOpen ${ }^{\circ}$ journal and benefit from:}

- Convenient online submission

- Rigorous peer review

- Open access: articles freely available online

- High visibility within the field

- Retaining the copyright to your article

Submit your next manuscript at $>$ springeropen.com 